\title{
Opening an imaginative space? A study of toys and toy play in a Swedish Waldorf preschool
}

\author{
Sara Frödén * and Anna-Lova Rosell \\ School of Humanities, Education and Social Sciences, Örebro University
}

\begin{abstract}
The aim of this study is to examine how the triadic relationship between children, toys and the educational context of a Waldorf preschool may contribute to children's growing imagination. The toys provided at Waldorf preschools in general are simple objects, and the selection is limited. Still, the toys are supposed to stimulate the imagination of children. In this analysis, we draw on Iris Murdoch's distinction between imagination and fantasy in order to highlight two qualities of the ability of imagination: Imagination implies openness and curiosity towards new ways of being and acting, and fantasy suggests a closed approach that offers few new possibilities. The distinction between these qualities enables us to examine how the relationship between children, toys and educational context opens or closes the children's growing imagination. The study identifies three particular factors that influence the possibilities for children's imagination. These are: a) the form of the toys; b) the placement of the toys; and c) the pedagogical intentions of the teachers and their interactions with the children.
\end{abstract}

Keywords: Imagination; Steiner Waldorf pedagogy; toys; early childhood education; play

Received: September, 2018; Accepted, April 2019; Published: September, 2019

\section{Introduction}

Toys are important artefacts, both in children's everyday lives and as educational materials and play tools in preschools. In the Waldorf preschool toys are primarily used to strengthen the children's development of creativity by stimulating their imagination. Indeed, Waldorf early childhood education can be viewed as a "pedagogy of imagination" (see Nielsen, 2004). Imagination expresses the holistic approach in Rudolf Steiner's thinking, which takes inspiration from romantic philosophical ideas that argue for the relevance of feelings and sense impressions in understanding and action (Mansikka, 2007). Steiner holds that imagination is not in contrast to cognition or perception but rather a binding link between them, and a vital part of creating wholeness and synthesis of human experience. For instance, in making sound

Correspondence: Sara Frödén, email: sara.froden@oru.se

(C) 2019 Sara Frödén og Anna-Lova Rosell. This is an Open Access article distributed under the terms of the Creative Commons Attribution 4.0 International License (http://creativecommons.org/licenses/by/4.0/), allowing third parties to copy and redistribute the material in any medium or format and to remix, transform, and build upon the material for any purpose, even commercially, provided the original work is properly cited and states its license.

Citation: Sara Frödén og Anna-Lova Rosell. "Opening an imaginative space? A study of toys and toy play in a Swedish Waldorf preschool.” Nordisk tidsskrift for pedagogikk og kritikk, Special Issue: «Steinerpedagogikk» Vol. 5, 2019, pp. 186-201. http://dx.doi.org/10.23865/ntpk.v5.1383 186 
decisions, imagination is thought to link one's perception of a situation, one's general understanding of what similar situations call for, and rules or values that provide us with guidance. This is a process that illustrates how imagination is thought to create wholeness and synthesis (Tyson, 2015). In Waldorf preschools but also in other similar early childhood educational settings, imagination can thus be considered a significant aspect of the everyday educational practice. Against this background, and in the context of the belief in the importance of promoting children's imagination, it is rather surprising that the toys provided in Waldorf preschools are simple objects, such as plain dolls, vehicles with vague shapes, Kapla blocks (plain wooden building blocks), and play cloth. In one of his lectures, Steiner (1906/2007) states that it is a mistake to give a child "beautiful dolls" with realistic features. Instead, he claims that the child will "be much happier with a piece of wood or with anything which gives his imagination a chance to be active" (Steiner, 1906/2007, p. 44). However, the assumption that simple toys activate children's emerging imagination has not been further explored in empirical research studies of Waldorf preschools. Accordingly, this study contributes to the field of research by shedding new light on this topic. We are using detailed data from an ethnographic study based on long-term fieldwork conducted in a Swedish Waldorf preschool. The aim of this study is to examine how the relationship between the children, the play items and the educational context of a Waldorf preschool may contribute to the children's growing imagination. We do this by drawing on philosopher Iris Murdoch's distinction between two qualities of imagination, imagination and fantasy, explained in detail below.

\section{Definition of toy and toy play}

In the most general sense, a toy can be defined as an object that is designed for children to play with. In Waldorf preschools, however, some items used in the children's play would, in another context, not be considered play object. Accordingly, the context plays an essential part in defining an object as a toy. As Alan Levinovitz (2017, p. 271) argues, toys can be understood as "physical objects that are conducive to the kind of interaction between subject, object and context".

In this study, we define toys as physical objects intended to be played with. We are thereby stressing the triadic relation in which the playing child, the play item and the educational context determine what is - or is not - a toy in the present play situation. In other words, by nuancing the definition of toys, we include play material such as pieces of wool or stones that the children in the Waldorf preschool use in play but that might be interpreted as mere decorations in another context. Furthermore, when using the word toy play, we refer to free play that involves toys and is self-chosen and initiated by the children. Toy play differs from gameplay as it lacks the established sets of rules connected with games and thus emphasizes the child's own agenda (Levinovitz, 2017). 


\section{Imagination and fantasy}

In order to analyze the relationship between the children, the toys and the educational context, we turn to moral philosopher Iris Murdoch's understanding of two aspects of imagination, namely imagination and fantasy. In her view, imagination is not just make-believe but an important part of how we understand the world. In the narratives we tell of our experiences in order to make sense of them, we use our imagination to fill in the blanks and create a coherent storyline that more or less reflects actual events (Widdows, 2005). By cultivating oneself morally one can become less self-centered, more attuned to the surrounding world and more open to the influence of the narratives of others.

The concepts of imagination and fantasy are described by Murdoch (2003, p. 321) as "different states of consciousness". However, they should not be viewed as dichotomous but rather as two aspects of creative ability that encircle a more or less open manner of relating to one's surroundings. Imagination means to "freely and creatively explor[e] the world" (Murdoch, 2003, p. 321). It takes us beyond the present, our own ideas and agendas, and it is an "exercise in overcoming oneself" (Murdoch, 1997, p. 216). It requires that we direct our attention away from egocentricity so that we can listen curiously to how others narrate their lives (Olsson, 2018). It is "the effortful ability to see what lies before one more clearly, more justly, to consider new possibilities, and to respond to good attachments and desires" (Murdoch, 2003, p. 322). Fantasy, on the other hand, is described as "egoistic, untruthful" (Murdoch, 2003, p. 321). It represents a self-centered quality of our imagination in which we mold our narratives based on our individual needs, dreams and fears or on general truths that give stability and comfort in an ever-changing world that might seem overwhelming. As such, the two concepts imply an open or a closed attitude to that which is new and unknown. Seen from this perspective, the qualities of imagination can thereby influence a child's relationship to the world (Altorf, 2008; Laverty, 2007; Murdoch, 2003).

Murdoch holds that imagination can be cultivated when we engage with our surrounding social and material world (Antonaccio, 2000; Murdoch, 1997). In her writing, literature and art constitute a frequent example of how one's focus can be directed away from the egocentric (Ruokonen, 2008) but also everyday sense impressions such as carefully holding a stone in one's hand. She writes that "[c]hildren, if they are lucky, are invited to attend to pictures or objects, or listen quietly to music or stories or verses, and readily understand in what spirit they are to treat these dissimilar things" (Murdoch, 2003, p. 3). However, an object or a story can also spur fantasy by offering a narrative that is enclosed in rigid understandings, which in turn may encourage further fantasy in the observers' or readers' own narratives.

Toys are not specifically mentioned in Murdoch's texts. Still, the emphasis on how inner creative qualities can be influenced by the narratives and objects that we interact with allows for a broader discussion about creativity and imagination. With this proviso, we use Murdoch's distinction between imagination and fantasy to examine the importance of the toys used in toy play and how they might support the growth of 
children's imagination. Consequently, this is also a question of encouraging a moral cultivation that entails an openness towards the surrounding world and a variety of possible ways of being and acting.

\section{The ethnographic fieldwork, ethical considerations, data and analysis process}

In this article, we use data from a broader ethnographic study which focuses on the material and spatial dimensions of a preschool practice. The study is based on fieldwork conducted over a period of one and a half years in a Swedish Waldorf preschool by one of the authors (Frödén, 2012). The methods used are participant observation and in-depth, semi-structured interviews with the two female Waldorf preschool teachers (hereafter referred to as teacher). The group of children that participated consists of nine girls and eight boys, between the ages of three to seven years old. The data consist of field notes, audio recordings and photographs of the rooms and artefacts. Since the Waldorf preschool is a low technological environment, where the teachers do not use cameras to document the practice, the photographs were taken without the children's presence so as to avoid any disturbance and the engendering of potential feelings of obtrusion or of being supervised.

Ethical considerations and meta-reflections, especially those concerning children's consent, were undertaken continuously throughout the entire fieldwork. The large amount of time spent in the same preschool supports the development of a close relationship, built on trust and reliance, between the researcher and the children. After a while, the researcher was warmly invited by the children to participate in their play. In the few situations where the children implicitly (with body language) or explicitly (with words) signaled that they found the researcher's presence or actions disturbing, this was respected and the researcher withdrew from the situation.

The long-term fieldwork also made it possible to discern distinct and recurring patterns by observing a substantial number of similar activities during a longer period, which results in more detailed data. Thus, only a few of the several so-called thick descriptions of toy play situations are presented here and are limited to interactions in the indoor environment, where the majority of the toys were placed. The selected examples include a range of different toys (see table 1) and toy play to illustrate the variety.

The analysis was conducted in several steps. Firstly, the preschool's physical environment was mapped in detail, with a particular focus on toys, using field notes and over 250 photos. Secondly, transcriptions of interviews that addressed the topic of toys were identified, and excerpts that involved toy play were divided into two categories, namely children's toy play, and toy play involving the teachers. Thirdly, the concepts of imagination and fantasy were used as tools to analyze how the relationship between children, toys and the educational context may contribute to children's growing imagination and which aspects of the three seemed to have the most influence. 


\section{Previous research, the Waldorf preschool environment and selection of toys}

There is a growing body of Nordic research on different aspects of materiality in preschools which shows how the physical environment and artefacts like toys have a great impact on children's play and creativity (Krogstad et al., 2017; Nordtømme, 2016; Rossholt, 2012; Nordin-Hultman, 2004). Likewise, post-humanist studies stress the agency of the non-human materiality and how it influences children's activities by offering and precluding certain possibilities (see Hultman, 2011). For instance, rooms and objects designed with clear pedagogical intentions and predetermined functions can reduce children's opportunities of developing more innovative play, whereas more flexible and transformative environments and toys have a greater potential for children to create more inventive dramatic play (Greve \& Kristensen, 2018; Eriksson Bergström, 2013). Playing with natural or recycled material that offer many different interpretations can lead to a greater variety of play, which also lasts longer as new ideas continuously arise. At the same time, such material is more demanding to play with since it often requires negotiations to reach a common agreement on its (not so obvious) use and function in the activity (Thorbergsen, 2017; Änggård, 2009; Hangaard Rasmussen, 2001).

In contrast, research on Waldorf preschool practices in general is scarce and does not specifically address toys. However, the descriptions of the preschool environment and the artefacts therein are strikingly similar in existing studies though they are from many different countries (Uhrmacher, 2004; Kraftl, 2006; Bone, 2007; Schwartz, 2008; Waiste \& Rees, 2013). Carefully designed rooms as well as a specific selection of toys are characteristic features of Waldorf preschool practices. All toys are made of natural materials, such as wood, wool or cotton, and are usually hand-crafted, often by the teachers. They have plain features, minimal details, simple shapes and soft colors (Frödén \& von Wright, 2017). In other words, common play objects such as plastic, ready-made, technological or digital toys and games are not to be found in Waldorf preschools (Schwartz, 2008). Furthermore, as a way of reducing the creation of fixed narratives by adults in preschool, there are no pictures, books, toys or games related to children's popular culture (Waiste \& Rees, 2013). Instead, the idea is to provide a more flexible and open-ended space in which children can play.

This notion is manifested in the environment of the Swedish Waldorf preschool in this study. It is typically designed with empty, soft-colored pink walls, minimal furniture and a limited number of toys that are openly displayed in the wellorganized yet changeable rooms. The main selection of toys, described by the teachers as "unfinished" and "not so fixed in its usage", is compiled in a table below. There is a mixture of toys in the rooms, as they are not divided according to activities and play, such as a doll corner or a building area. The toys are all placed at a convenient height for the children, and they were regularly cleared away by the children and teachers during the day to make space for new activities during the day. This means that the adaptable rooms have recurrent starting positions: when the children enter a room 
after playing outdoors, there are no traces of the previous play performed there. Yet the toys are located in the same places, which facilitates the beginning of a new play session with the same play material. The daily cleaning routine also becomes a way of caring and showing respect for the toys, as illustrated by Parker-Rees \& Rees (2011) in their study of a British Waldorf preschool "At the end of the day, each doll is wrapped in a blanket and put to bed, and the children also learn to treat other materials with respect; pieces of cloth are folded, ropes are coiled and everything has its place" (p. 42).

One of the teachers in the present study, Erica, also expressed that considerable emphasis is placed on taking care of the toys: "Through the years, you can see that we really put great effort into caring for our toys in the preschool". The fact that the children watch the teachers making and mending toys during the daily educational practice also instills in them a respectful attitude and behavior towards the play items.

Below follows a table of the main selection of toys found in the studied preschool. In the following four sections of the article, we proceed to present our analysis of the two categories that were identified: children's toy play and toy play involving the teachers.

Table 1 Main selection of toys

\begin{tabular}{|c|c|c|c|c|}
\hline Play material & Construction toys & Dolls/animal figures & Vehicles & Dressing up-outfits \\
\hline \multirow{11}{*}{$\begin{array}{l}\text { Natural objects: } \\
\text { Shells, stones, } \\
\text { pine cones, } \\
\text { sticks, seeds, } \\
\text { nuts }\end{array}$} & Wooden and ceramic & Soft dolls, fairy tale & \multirow{11}{*}{$\begin{array}{l}\text { Wooden cars, } \\
\text { trucks, wagons and } \\
\text { boats }\end{array}$} & \multirow{11}{*}{$\begin{array}{l}\text { Crowns, lace veils, } \\
\text { plain skirts, shawls } \\
\text { and cloaks of cotton } \\
\text { or silk }\end{array}$} \\
\hline & bricks and blocks in & figurines, swaddle & & \\
\hline & varying shapes and & baby dolls, puppets for & & \\
\hline & sizes and soft colors & theatre purposes, & & \\
\hline & & doll clothing & & \\
\hline & Simple wooden & and carriages & & \\
\hline & construction toys, & & & \\
\hline & play cloths, ropes, & Wooden or stuffed & & \\
\hline & strings and clothes & animal figurines & & \\
\hline & pegs for building & & & \\
\hline & cubby-holes & Hobbyhorses & & \\
\hline
\end{tabular}

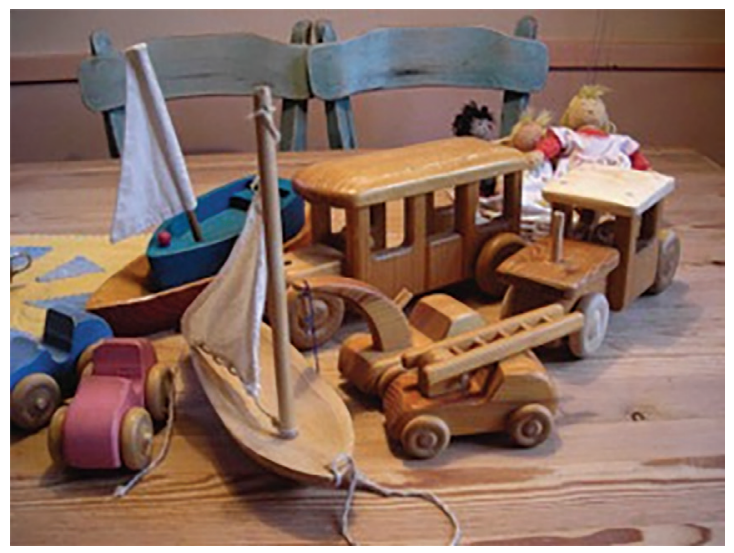

Illustration 1 Handmade dolls and wooden vehicles. 


\section{Transformable toys and a variety of play themes and characters}

In the following four sections of the article, we present our analysis of the two categories that were identified, namely children's toy play and toy play that also involved the teachers. During the fieldwork, girls and boys played together in various mixed-age groups. They often played dramatic role-playing games with a variety of themes and enacted a wide repertoire of characters. The dress up outfits consisted for instance of plain, handmade one-colored veils and cloaks (see table above) which lacked reference to professions and popular culture characters. They were popular toys, and the same cloak was used in the performance of different roles, including a prince, an animal and a robot servant. The following excerpt illustrates how the children negotiate potential roles in the play by using these toys.

\section{Excerpt 1: Princess, mermaid, pirate or knight?}

Two girls, Matilda (five years old) and Nova (three and a half years), are standing by the dressing up outfits that are hanging on hangers in the hall. They are trying on different clothes and items. Nova is pointing at the white lace veils in Matilda's hand: "I want to have one of those ... and be a princess."

They argue about which veil to wear, and Nova finally decides to put on the smaller one.

Matilda: "Ok, but there is a small and a big one. And we are mermaids."

At the same time, two boys, Sebastian (three and a half years old) and Tim (five years), are passing by and stop.

Sebastian: "Can I join in?"

Nova turns to the boys: "Yes. We are playing mermaids. Do you want to be mermaid?"

Sebastian: "Yes, I would like to be mermaid". He steps forward and takes a blue silk cloak from the hook.

Tim (hesitating): "Or ... We can be pirates?"

Matilda: "No, we cannot be pirates."

Nova: "Mermaid."

Tim says something in a low voice, and Matilda agrees: "Well, ok".

Another boy, Nils (five years old) comes along and asks: "What are you playing?"

At first, no one notices him. They are trying on different cloaks, skirts, crowns and veils and helping each other out with the costumes.

Nils goes directly to Matilda and asks in a higher voice: "Can I join in?"

Matilda: "We are playing mermaids. Sure, you can join in. But then you get to be ... a knight, if you like".

When they are satisfied with their costume choices, they start creating the play's storyline together and include all the different characters.

The dressing up outfits invite the children to play with them, but not because they have a form immediately associated with mermaids or knights. Instead, these plain items are interpreted as toys due to the educational context: their placement (high accessibility by hanging visibly in the hall), and the pedagogical intention (they 
are intended to be played with). The simple shape of the toys can also be interpreted as supporting the children's imagination: the materials are not related to an established narrative with specific characters nor bound to a certain gameplay. As such, they do not invite them to play a particular play. The children can easily transform the plain pieces of cloth into a costume that fits a role in the dramatic play they are forming together and the plain material make it possible to create a greater variety of characters. On the other hand, since the material offers many possible interpretations, the play can also require a great amount of effort in order for the children to agree about the roles in the play. The plain cloth can thus create a possibility for the children to meet in an imaginative space wherein they can carefully listen to each other and allow their narratives to be continuously recreated as they go along.

\section{The negotiation of predetermined narratives brought in by the children}

Despite the absence of toys and games related to popular culture in the preschool environment, the children themselves occasionally bring these narratives into preschool, which offers us an opportunity to explore how it may influence their play. For instance, Star Wars was a dominant theme for a long period and was introduced by an older boy, Nathan (six and a half years old). Seeing as few of the other children had seen the Star Wars films, he was proud and eager to share his knowledge. After a while, most of them knew the names of the characters, the spaceships and different places in the universe from the story. However, the other children changed the personality of the characters and created new stories together that differed from the original in many ways. Nathan long persisted in trying to correct his peers by telling them "the real story", but few of them were willing to listen to his lectures and follow his predetermined storyboard. The lack of Star Wars-related items or pictures in the preschool resulted in the usage of the available toys: the children built spaceships out of wooden blocks, used sticks as laser swords, pot lids as shields and dressed in cloaks. After much negotiation, Nathan and the other children agreed on a new joint narrative that diverged from what he originally proposed.

The example of Nathan shows a situation that can be understood through fantasy. Nathan has experienced a narrative that has a rather fixed beginning, middle and end. The characters and storyboard are established before the play begins, which makes it hard for him to create a new imaginary world when participating in play with a Star Wars theme. Nathan is momentarily captured and enclosed in fantasy, here interpreted as a quality that implies a difficulty to attend to, or a lack of interest in, the narratives of others. The other children, who do not share his understanding of the Star Wars story, are inspired solely by his oral storytelling and are picturing the characters and their surroundings differently. The simple form of the toys, which has very few similarities to the objects in the Star Wars films, makes it even more difficult for Nathan to persuade the others to reproduce the original 
tale in their common toy play. Instead, the children have to imagine the described scenarios by filling in the blanks themselves with no guidance from the materials around them. Further, the educational context, which has no toys, pictures, books or films that support Nathans narrative, are contributing to the creation of a continuously changing mutual toy play. Nathan eventually moves from the self-centered focus of fantasy towards imagination, which suggests a further openness towards a greater variety of possible narratives.

\section{Inviting the teacher into the toy play}

As indicated in the example above, the construction toys were given multiple meanings even in play with realistic themes. That is, they were used by the children not only for building houses and fences in multifaceted, pretend landscapes filled with dolls/figurines and vehicles. For instance, three boys were using Kapla blocks to bake cakes. They then placed the "cakes" in a baby carriage and sold them to the rest of the group. Pretending to run a bakery or shop were recurring themes of "reality" play, and the following excerpt shows how the children involved the teacher in such a toy play.

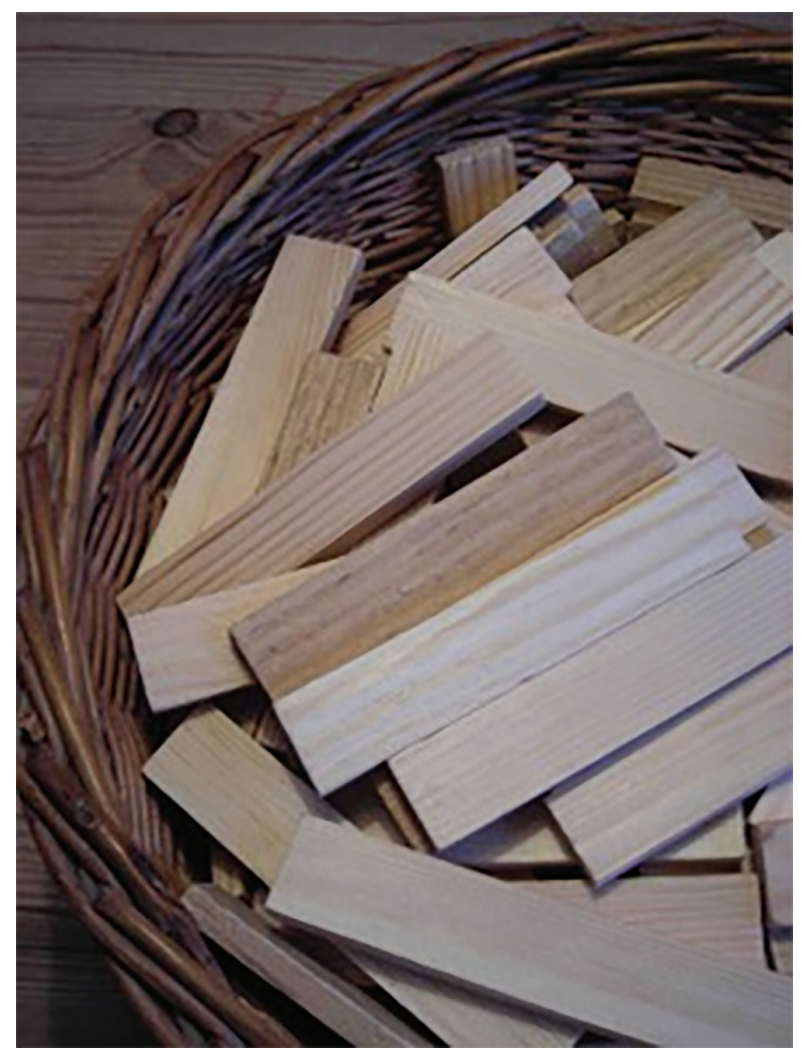

Illustration 2 Basket of Kapla blocks. 


\section{Excerpt 2: The shop play}

One of the rooms has been turned into a shop by Ester (four years old), Tim, and Matilda (five years). They have transformed a low bench into a cash desk by decorating it with a play cloth and placing shells, stones and toy vehicles on it as well a flat wooden tablet, which works as a cash register. They are standing behind the desk and waiting for customers to come.

Matilda (pensive voice): "Well, they have to pay. ..."

Tim: "Yes, the pieces of wood can be money."

Matilda goes away and brings back a bunch of Kapla blocks. The teacher, Anna, comes into the room.

Ester: "Do you want to come and buy something?"

Anna goes to the desk: "What have you got?"

Matilda: "We've got toys."

Anna looks at the bench, hesitating: "Well ... I would like to have ..."

Tim looks at the bench: "We've got stones. Smooth stones." Then he stops and looks up at her. In a quick, discrete move, he gives her the Kapla blocks and says in a low voice: "Here you go!"

Anna receives the Kapla blocks and looks at them, pretending to count them, and holds them up to show the children: What can I get with these?

Tim points at some other things on the bench: "These".

Anna: "Hmmm, but you said you had smooth stones. Oh, here you've got some!" She picks a couple of stones and gives the "money" to Tim, who puts them under the "cash register". "Oh, thanks! What a good shop!"

The children invite the teacher to play with them. She partakes in the expected role of a customer and participates on the children's terms by agreeing to the suggested changed meaning of the objects. During the play, the transformation of the toys into pretend everyday items needs to be accepted by all the players, including the teacher: when Tim gives the Kapla blocks to Anna, he expects her to understand without explanation that he is giving her money so she can start shopping. She is only visiting the children's play, not directing or trying to change it. Instead, she is supporting their mutual understanding of the play's theme and following their storyline. Hence, she is not forcing her own narrative on them (fantasy) but encouraging the children's imagination through her actions by temporarily entering their imaginative space. In the next example, though, the same teacher acts in a different way.

\section{The swaddle baby doll as an object of attachment and animated play item}

The dolls in the preschool vary in size, in color of skin and hair but they have the same minimal facial features. The soft swaddle dolls are also simple, made of varied skin-colored cotton and stuffed with wool, but differ from the other dolls due to their baby-like appearance: big, bald heads with hand-knitted baby caps and shapeless bodies wrapped in soft cloth, placed together in groups in large baskets that function 
as beds. The dolls are usually handmade by the parents (with instructions from the teachers) and given to the children before they start at preschool and subsequently brought home when they start school.

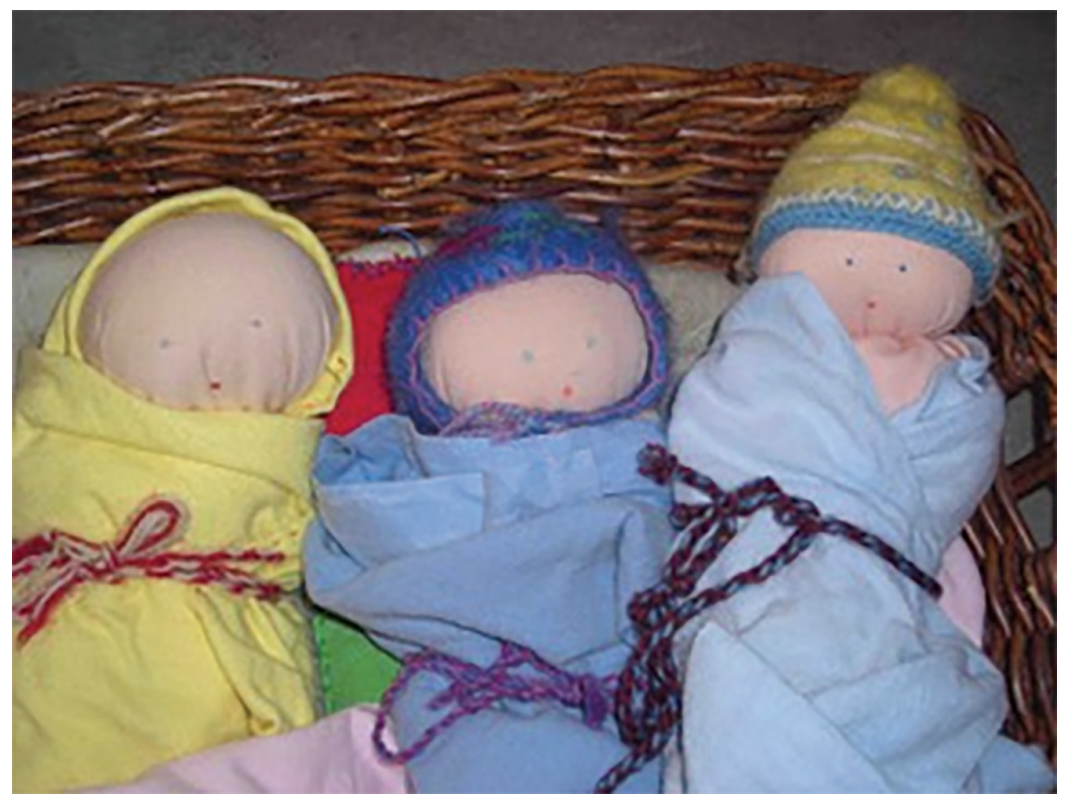

Illustration 3 Swaddle baby dolls.

According to the teachers, the swaddle baby dolls are made for two main reasons. For the younger ones, the doll accompanies them during nap-time. So, instead of bringing comfort blankets or toys from home into preschool, every child has their own swaddle baby doll, which all look similar but have a personal touch as each one is made by the child's parent: "Something just for their child. ... It is a comfort to have it. It is mine nobody else's" (teacher, Anna). The second reason is to encourage the children to play in a nurturing and caring way, in order for them to learn "how to hold and what to do with a little baby, how to take care of it" (teacher, Anna). In contrast to other free toy play, the teachers highlighted the need to promote this doll play: "It depends on us and it also comes and goes. ... If there are several children who receive their swaddle baby dolls during the autumn or are sewing their own doll - then it becomes alive! Then perhaps we can throw a swaddle baby doll party ..." (teacher, Erica).

During such a party, the dolls attend circle time with the children, who sing songs and bake cakes for them, as a way of getting the children to pay more attention to the dolls. The teachers' intention of inspiring a certain play theme, in this case caring for an infant, led to a disapproval of other sorts of play with the swaddle dolls. For instance, when the dolls were placed in individual open box beds, the children used the boxes as cars and played a racing game, which was questioned by the teacher Anna: "Well, that was not a nice thing to do, bumping them over the doorstep so the 
swaddle baby doll goes flying. That's not what we do in real life ... [...] The tenderness disappeared." During the fieldwork however, it became evident that the swaddle baby doll was the least popular toy to play with, which the teachers confirmed: after the dolls had eventually been moved into a common bed basket, the children very seldom played with them.

The swaddle dolls differ from the other toys as they carry a more fixed narrative (that of an infant), which can lead the children into the narrowness of fantasy. Besides their baby-like form, their placement (in "beds") contributes to this rigidity, but in this example, the pedagogical intentions of the teachers are especially influential: by animating the dolls as infants, the children are supported to develop a close relationship with these toys. At the same time, the teachers view the swaddle baby dolls more as objects of attachment than as play items, and due to this view certain play is endorsed and other plays are dismissed. Hence, they create an enclosed narrative, and, by accepting the predetermined story, the children are more likely to relate to them in terms of fantasy. A fantasy can be a self-indulgent desire to subordinate experiences under specific truths or set narratives. When fantasy dominates, it becomes increasingly more difficult for the child to move beyond that which is familiar and known and to imagine that things could be different. Nevertheless, the children in this example resisted. They played racing car games (imagination) - a play that is far from the teacher's preferred caring play. Also, they resisted, by choosing not to play with the swaddle dolls.

\section{Concluding discussion}

This study has explored the relationship between children, toys and the educational context of a Waldorf preschool and how this dynamic may contribute to children's growing imagination. The data of the study has been analyzed through the concepts of imagination and fantasy, which represent two qualities of the ability to imagine. Imagination implies openness and curiosity towards new ways of being and acting. Fantasy, on the other hand, suggests egocentricity and a narrowness of perspectives (Murdoch, 1997, 2003; Laverty, 2007). The distinction between these two qualities helps us examine how the triadic relationship broadens or stifles the children's growing imagination. This study shows examples of when the relationship contains qualities of imagination, as in the example of the children playing with dressing up outfits. They negotiate the play's storyline as they go along, and, since none of them seem to have a fixed narrative in mind, this possibility opens up a shared imaginative space. The findings also illustrate situations marked by fantasy, as in the example of Nathan. His insistence upon sticking closely to the original story of Star Wars makes it a challenge for him to see other possibilities, and he is momentarily enclosed in fantasy.

As imagination grows, one's ability to appreciate that another person's life and reality can be different from one's own increases. From Murdoch's perspective, imagination opens us not only to further exploration and expanded perspectives but also to the cultivation of moral qualities that can influence how one relates to others in 
social situations (Laverty, 2007). The findings of this study are therefore important to consider. They suggest several implications for educational practice, and it is likely that the processes of imagination are not limited to Waldorf preschools but might also be of relevance to other educational settings organized in similar ways. The results point to factors within the triadic relationship that create possibilities for the quality of both imagination and fantasy to expand. The most significant factors found are a) the form of the toys, b) the placement of the toys, and c) the pedagogical intentions of the teachers and their interactions with the children.

Firstly, in relation to the form of the toys, Murdoch $(1997,2003)$ stresses that imagination and fantasy are deeply connected to our surroundings and that the objects we interact with can spur the different qualities. In this preschool, the toys are often rather plain, e.g. dolls with few facial and bodily features or natural objects, such as cones or blocks of wood. The form of the toys do not call upon the children to play a particular play, and the form does not entirely enclose around a fixed narrative. As such, the toys contribute to the triadic relationship of toy play characterized by open-endedness and a mutual creation of the make-believe world (Beckett, 2010).

Secondly, due to the placement of the toys, they catch the attention of children and invite them to play despite their simple form, as the toys are placed clearly visible and at a child-adjusted height, in carefully designed yet adaptable rooms. The teachers also contribute to the transformation of everyday objects such as stones and sticks into play items by placing these on shelves next to more conventional toys. In this way, the stones are presented as play objects to use in various ways. The mixture of toys also encourages the children to play a great variety of play.

Finally, there is an overall pedagogical intention from the teachers that the children should form a close bond with the toys by relating to them with respect in the process of producing and caring for them. The teachers act as role models by making and mending the toys as part of their everyday pedagogical practice and by collecting play material from the natural surroundings of the preschool along with the children. In the case of the swaddle baby dolls, the teachers even animate them in order for them to function as attachment objects. These actions are all part of the teachers' intentions to encourage the children to develop a caring attitude and to help them to approach their toy play with imagination, that is, with careful attention and a respect towards the specific object or person with whom they interact. However, it is also clear that the balance between imagination and fantasy is a fine one. In the case of the swaddle baby dolls, this intention can support fantasy as well; the teachers expect the children to view the dolls as fragile infants and certainly not race car drivers. The swaddle baby dolls offer little space for the children's own creativity in the toy play and seems to create an enclosed narrative that cannot accommodate the children's imagination. Instead of a caring attitude, the dolls create resistance and weakens the relationship between the dolls and the children. When they have to accept the predetermined narrative of the teachers', the relationship between the children and the toys becomes marked by fantasy and the children's perspectives risk becoming narrower. 
In summation, this study shows that the factors above contribute to the creation of an imaginative space in which the children can develop their sense of imagination.

However, the findings of this study can pose a challenge both to teachers and children. They suggest that an imaginative space cannot come about when play situations are restricted by set requirements or are too closely controlled. Conversely, children who are high media-consumers and who are more used to high tech interactive toys and computer games might find it demanding to play with simple play items that have no a backstory, set instructions or rules. Indeed, imagination can be viewed as an effortful ability (Murdoch, 2003) that needs a space of open-endedness and surprise, which can be inspiring as well as frightening. The development of imagination also requires what Cynthia Beckett (2010, p. 198) refers to as "a holding environment": that is, a "secure, dependable setting that allows for formlessness to be present". Such an environment has a framework of certain predictable and recurrent features and routines that make all children feel secure and can allow for moments of imagination and surprise to come about. The tension between predictability and unpredictability is not so much a contradiction as a necessary foundation for imagination: "A holding environment is about a safe and structured circumstance that is at the same time not an imposing structure", continues Beckett (2010, p. 198). Thus, the task of the teacher is not only to provide certain toys that encourage imagination but also to design an environment that balances this tension with unpredictability and allows children to feel safe to express themselves in the free toy play.

In conclusion, according to Murdoch (2003), fantasy may dampen our imagination, silence our curiosities about our world and lead to a failure to understand the difficulties of grasping a versatile reality. Imagination is an important aspect of an educational context as it can open possibilities of growing as a moral individual. It means that you allow for your values and beliefs to be challenged and that you allow yourself to explore different ways of being and acting. Still, it is an imagination that does not distort or violate our surroundings. This can be a rewarding challenge for both children and teachers to take on.

\section{About the authors}

Sara Frödén is a senior lecturer in education at The School of Humanities, Education and Social Sciences at Örebro University, Sweden. Her current research focuses on children's play, children's rights in education, school meals and education for sustainable development.

Anna-Lova Rosell is a senior lecturer in education at The School of Humanities, Education and Social Sciences at Örebro University, Sweden. Her fields of interest are philosophy of education, bildung and moral formation as well as imagination and attention in education. 


\section{Sara Frödén and Anna-Lova Rosell}

\section{References}

Änggård, E. (2009). Skogen som lekplats. Naturens material och miljöer som resurser i lek. Nordisk pedagogik, 29, 221-23.

Altorf, M. (2008). Iris Murdoch and the Art of Imagining. London: Continuum.

Beckett, C. A. (2010). Imaginative Education explored through the concept of playing in the in between. In T. W. Nielsen (Ed.), Imagination in Educational Theory and Practice: A many-sided vision. Cambridge: Cambridge Scholars Publishing.

Bone, J. (2007). Everyday spirituality: Supporting the spiritual experience of young children in three early childhood educational settings. Diss. Palmerston North: Massey University.

Eriksson Bergström, S. (2013). Rum, barn och pedagoger: Om möjligheter och begränsningar i förskolans miljö. Diss. Umeå: Umeå universitet.

Frödén, S. (2012). I föränderliga och slutna rosa rum. En etnografisk studie av kön, ålder och andlighet $i$ en svenska waldorfförskola. Diss. Örebro: Örebro universitet.

Frödén, S., \& von Wright, M. (2017). The Waldorf kindergarten. In M. Fleer \& B. Van Oers (Eds.), International Handbook of Early Childhood Education. Dordrecht: Springer.

Greve, A., \& Kristensen, K. O. (2018). Når det fiktive stedet møter det fysiske rommet: Rommets betydning for dramatisk lek. In S. Seim \& O. Sæter (Eds.), Barn og unge. By, sted og sosiomaterialitet. Cappelen Damm Akademisk/NOASP.

Hangaard Rasmussen, T. (2001). Legetøjets virtuella verden: Essays om legetøj og leg. Brøndby: Semi-forlaget.

Hultman, K. (2011). Barn, linjaler och andra aktörer: Posthumanistiska perspektiv på subjektsskapande och materialitet i förskola/skola. Diss. Stockholm: Institutionen för pedagogik och didaktik. Stockholms universitet.

Kraftl, P. (2006). Building an idea: The material construction of an ideal childhood. Transactions of the Institute of British Geographers, 31(4), 488-504.

Krogstad, A., Hansen, G. K., Høyland, K., \& Moser, T. (Eds.) (2017). Rom for barnehage: Flerfaglige perspektiver på barnehagens fysiske miljø. Bergen: Fagbokforlaget.

Laverty, M. (2007). Iris Murdoch's ethics: A consideration of her romantic vision. London: Continuum.

Levinovitz, A. (2017). Towards a theory of toys and toy-play. Human Studies, 40, 267-284.

Mansikka, J.-E. (2007). Om naturens förvandlingar:Vetenskap, kunskap och frihet $i$ Rudolf Steiners tidiga tänkande. Idéhistoriska perspektiv på Waldorfpedagogiken. Diss. Pedagogiska institutionen. Forskningsrapport 211. Helsinki: Helsinki University.

Murdoch, I. (1992/2003). Metaphysics as a Guide to Morals. London: Vintage.

Murdoch, I. (1997). Existentialists and Mystics:Writings on philosophy and literature. London: Penguin.

Nielsen, T. W. (2004). Rudolf Steiner's pedagogy of imagination: A case study of holistic education. Bern: P. Lang.

Nordin-Hultman, E. (2004). Pedagogiska miljöer och barns subjektsskapande. Diss. Stockholm: Stockholms universitet.

Nordtømme, S. (2016). På vei mot en rom(s) lig pedagogikk: En fortolkende studie av barns lekeerfaringer med rom og materialitet. Diss. Kongsberg: Høgskolen i Sørøst-Norge.

Olsson, A.-L. (2018). A moment of letting go: Iris Murdoch and the transformative process of Unselfing. Fournal of Philosophy of Education, 52(1), 163-177.

Parker-Rees, R. \& Rees, S. (2011). How the Steiner kindergarten environment helps adults and children to get to know each other. In R. Parker-Rees (Ed.) Meeting the child in Steiner Kindergartens: An exploration of beliefs, values and practices. New York: Routledge.

Rossholt, N. (2012). Kroppens tilblivelse i tid og rom: Analyser av materielle-diskursive hendelser $i$ barnehagen. Diss. Trondheim: Norges teknisk-naturvitenskapligeuniversitet.

Ruokonen, F. (2008). Iris Murdoch and the Extraordinary Ambiguity of Art. The fournal of Value Inquiry 42(4), 77-90.

Schwartz, E. (2008). From playing to thinking. How the kindergarten provides a foundation for scientific understanding. European fournal of Psychotherapy and Counselling, 10(2), 137-145.

Steiner, R. (1906/2007). Founding a science of the spirit. Fourteen lectures given in Stuttgart between 22 August and 4 September 1906. Sussex: Rudolf Steiner Press.

Thorbergsen, E. (2017). Lekemateriell og barns lek. In A. Krogstad, G. K. Hansen, K. Høyland \& T. Moser (Eds.), Rom for barnehage: Flerfaglige perspektiver på barnehagens fysiske miljø. Bergen: Fagbokforlaget.

Tyson, R. (2015). Imagination at the center of moral action: Developing a deeper understanding of how to educate for teacher excellence. Research on Steiner Education, 6, 46-56. 


\section{Opening an imaginative space?}

Uhrmacher, B. (2004). An environment for developing souls: The ideas of Rudolf Steiner. In D. Callejo Pérez, S. Fain \& J. Slater (Eds.), Pedagogy of place: Seeing space as cultural education. New York \& Washington: Peter Lang.

Waite, S. \& Rees, S. (2013). Practicing empathy: Enacting alternative perspectives through imaginative play. Cambridge fournal of Education, 44(1), 1-18.

Widdows, H. (2005). The MoralVision of Iris Murdoch. Aldershot: Ashgate. 